\title{
Bio-efficacy of tank mixed herbicides for control of complex weed flora in soybean (Glycine max L. Merril)
}

\author{
Mahender Singh $^{1 *}$, I. S. Tomar ${ }^{1}$, J. Morya ${ }^{1}$, Arjun K. Verma ${ }^{2}$ and R. K. Tripati ${ }^{1}$ \\ ${ }^{1}$ Zonal Agricultural Research Station, Jhabua, Rajmata Vijayaraje Scindia Krishi Vishwa Vidyalaya, Gwalior - \\ 474003 (M.P.), INDIA \\ ${ }^{2}$ Krishi Vigyan Kendra, Jhalawar, Agriculture University, Kota -324007 (Rajasthan), INDIA \\ *Corresponding author. E-mail: msjadon2000@rediffmail.com
}

Received: April 1, 2016; Revised received: September 2, 2016; Accepted: November 30, 2016

\begin{abstract}
A field experiment was conducted at ZARS, Jhabua (M.P.) during kharif 2014 to find out most suitable and efficient method of weed control in soybean. The experiment consisted of nine treatments laid out in randomized block design with three replications. All the weed management practices led to significant reduction in density and dry matter of weeds as compared to weedy check. Two hand weeding (20 \& 40 DAS) recorded lowest weed density $\left(4.9 / \mathrm{m}^{2}\right)$, weed dry matter $\left(22.35 \mathrm{~g} / \mathrm{m}^{2}\right)$ with highest weed control efficiency of $59.67 \%$ and found at par with the application of Chlorimuron Ethyl @ 9gm /ha + Quizalofop-p-ethyl @ $50 \mathrm{~g} /$ ha (density 5.48/ $\mathrm{m}^{2}$, dry matter 26.62 $\mathrm{g} / \mathrm{m}^{2}$ and WCE of $51.97 \%$ ) and Imazethapyr @ $35 \mathrm{~g} / \mathrm{ha}+$ Imazamox @ $35 \mathrm{~g} / \mathrm{ha}$ (density 6.13/ m², dry matter 26.00 $\mathrm{g} / \mathrm{m}^{2}$ and WCE of $53.08 \%$ ). Maximum yield of $1782 \mathrm{~kg} / \mathrm{ha}$ was recorded in two hand weeding (20 \& 40 DAS) closely followed by Chlorimuron Ethyl @ 9gm /ha + Quizalofop-p-ethyl @ $50 \mathrm{~g} / \mathrm{ha}(1723 \mathrm{~kg} / \mathrm{ha})$ and Imazethapyr @ $35 \mathrm{~g} /$ ha + Imazamox @ $35 \mathrm{~g} / \mathrm{ha}(1697 \mathrm{~kg} / \mathrm{ha})$. Reduction in soybean yield in weedy check to be recorded is 38.78 per cent when compared to weed free and 36.68 per cent in comparison to Chlorimuron Ethyl @ 9gm /ha + Quizalofopp-ethyl @ $50 \mathrm{~g} / \mathrm{ha}$. However, highest Benefit to Cost ratio is recorded in Chlorimuron Ethyl +Quizalofop-p-ethyl (3.26) closely followed by Imazethapyr + Imazamox (3.22) and Weed free (3.21).
\end{abstract}

Keywords: Imazethapry, Pendimethalin, Quizalofop-p-ethyl, Soybean, Weed control

\section{INTRODUCTION}

Soybean (Glycine max (L.) Merrill) is called "Miracle crop" because of its multiple qualities. It provides $40 \%$ protein and $20 \%$ edible oil. Soybean is an important oilseed crop of Madhya Pradesh and emerged as a potential crop and brings prosperity of the farmers of Madhya Pradesh. It is grown over an area of 6.03 million hectare with the production of 7.80 million tonnes. Although the ecological conditions of the state are congenial for soybean production, but the productivity is low $(1293 \mathrm{~kg} / \mathrm{ha})$ as compared to national productivity of $1353 \mathrm{~kg} / \mathrm{ha}$ (Anonymous, 2014). Being a rainy season crop, it suffers severely due to excessive weed infestation. Severe weed competition is one of the major constraints for low productivity of soybean. The various grassy and broad leaf weeds compete for essential nutrients, moisture, sunlight and space especially during the first 40 days after sowing and cause substantial losses in the yield to the range of 25 to $70 \%$ depending upon the weed flora and intensity (Chandel and Saxena, 1998, Kewat et at., 2000 and Singh, 2007). Hand/ mechanical weeding is a traditional and effective method of weed control but untimely continuous rains and unavailability of labour at peak time are main limitations of manual weeding. In such circum- stances, the only alternative that needs to be explored is the use of herbicides. Use of only single herbicides is also not so effective as some weeds escape to control due to their selectivity. Therefore, integrated weed management or herbicide mixture may broaden the window of weed management by broad-spectrum weed control. Bineet et al. (2001) and Malik et al. (2006) suggested that sequential application of herbicides may provide consistent weed control than single application. Therefore, this study was conducted to assess the possibility of pre-emergent / post-emergent or integration of two herbicides for effective weed control in soybean.

\section{MATERIALS AND METHODS}

A field experiment was conducted at Zonal Agricultural Research Station, Jhabua (M.P.) during kharif 2014. The soil of the experimental field was loamy sand in texture, normal in soil reaction ( $\mathrm{pH} 7.6)$, low in organic carbon $(0.47 \%)$ and available nitrogen $(229 \mathrm{~kg} / \mathrm{ha})$, medium in available phosphorus $(13.2 \mathrm{~kg} / \mathrm{ha})$ and potassium (294 kg/ha). The field experiment was laid out in Randomized Block Design (RBD) with three replications. The experiment consisted of nine treatments viz., Weedy check, Weed free (Twice weeding at 20 \& 40 DAS), Pendimethalin@1.0 kg/ah, Chlorimuron 
Ethyl@09gm /ha, Imazethapyr@100 g /ha, Quizalofop-p-ethyl@50g/ha, Pendimethilene@1.0 kg/ha+ Interculture at 20 DAS, Chlorimuron Ethyl @ 09gm / ha+Quizalofop--ethyl@50 g /ha., Imazethapyr@35 g /ha+Imazamox@35 g/ha. Pendimethalin was applied as pre-emergence next day after sowing, while chlorimuron ethyl, imazethapyr quizalofop-ethyl and imazamox were applied as post emergence at 20 DAS as per treatment details (Table 1). All the herbicides were applied by manually operated knapsack sprayer fitted with the flat fan nozzle using spray volume of $500 \mathrm{~L} /$ ha. Soybean variety JS 335 was sown in first week of July and harvested in second week of October with recommended packages of practices. Fertilizers were applied uniformly at 20,60 and $20 \mathrm{~kg} \mathrm{~N}, \mathrm{P}$ and $\mathrm{K} /$ ha. Total precipitation during the season was 759.6 $\mathrm{mm}$ with 38 rainy days, which were 10.2 per cent less compared than average rainfall of the district $(845$ $\mathrm{mm}$ ). The observation on weed density were recorded at 50 DAS from a randomly selected area measuring $50 \times 50 \mathrm{~cm}$ from each plot and then converted to weed count per $\mathrm{m}^{2}$ area. The data on weed density were subjected to square root transformation i.e. $\sqrt{ }(\mathrm{X}+0.5)$ before statistical analysis to normalize their distribution. Weeds after taking the weed count data were first dried in the sun and then kept in an electric oven for 72 hours. Weed control efficiency (WCE) was calculated on the basis of weed dry mater by using the standard formula. The economic analysis of each treatment was done on the basis of prevailing market prices of the inputs used and outputs obtained under each treatment.

\section{RESULTS AND DISCUSSION}

Weed flora: The major weed species found in the soybean experimental plots were Cyperus rotundus, Cyperum irria ( sedges), Cynodon dactylon, Dactyloctenium aegyptium, Echinochloa colonum, E. crusgalli, (grasses), Ageratum conyzoides, Amaranthus viridis, Celosia argentia, Commelina benghalensis, Digera arvensis, Euphorbia hirta, Portulaca oleracea, Tridex procumbans and Xanthomonas strumarium ( broadleaf weeds). Among different categories, broadleaf weeds were recorded in higher number followed by grasses and sedges.

Weed density and weed dry weight: All the weed management practices caused the significant reduction in monocot and dicot weeds at 50 DAS. Significantly lower density of monocot and dicot weeds were recorded in twice hand weeding done at 20 and 40 DAS, however it was statistically at par with Chlorimuron Ethyl @ 09 gm /ha + Quizalofop-ethyl @ 50 g /ha (Table:1)

Among herbicidal treatments, tank mix herbicides i.e., Chlorimuron Ethyl@09gm /ha + Quizalofop-ethyl @ $50 \mathrm{~g} / \mathrm{ha}$ and Imazethapyr @35 g/ha+Imazamox@ $35 \mathrm{~g} / \mathrm{ha}$ were more effecting in reducing the weed population as compared to alone application of Pendimethalin PE, Chlorimuron Ethyl PoE, Imazethapyr PoE and Pendimethalin PE+ Interculture at 20 DAS and found at par with each other, whereas all the weed control treatments were significantly superior to weedy check in respect to reduce the weed population of weeds at 50 DAS stage of crop growth. Singh et al. (2015) also reported that tank mix herbicides of Chlorimuron Ethyl + Quizalofop-ethyl and Imazethapyr + Imazamox significantly reduced the weed density as compared to weedy check. Chlorimuron Ethyl + Quizalofopethyl reduced the weed density by $31.69 \%$ while Imazethapyr + Imazamox reduced by 45.58 as compared to farmers practice (weed density 8.93/ sqm). However among sole herbicides Quizalofop-p-ethyl effectively control monocot weeds while Imazethapyr controls dicots weeds as compared to other sole herbicides.

Weed dry matter were also effectively reduced by tank mix herbicides i.e., Chlorimuron Ethyl@09gm/ha + Quizalofop-ethyl@50g/ha and Imazethapyr@35 g /ha+Imazamox@35 g/ha and found at par with weed free treatment (Table:2). Lowest total weed dry matter $(22.35 \mathrm{~g} / \mathrm{m} 2)$ was recorded in weed free (twice hand weeding) treatment and it was closely at par with Chlorimuron Ethyl a + Quizalofop-ethyl (26.62 g/m2) and Imazethapyr + Imazamox $(26.00 \mathrm{~g} / \mathrm{m} 2)$. The maximum weed control efficiency of 59.67 recorded in weed free treatment followed by Imazethapyr @ 35 g /ha+Imazamox@35 g/ha (53.08\%) and Chlorimuron Ethyl@09gm /ha + Quizalofop-p-ethyl@ $50 \mathrm{~g} / \mathrm{ha}$ (51.97\%). Prachand et al. (2015) also reported higher weed control efficiency in Imazethapyr + Imazamox $(56.5 \%)$ as compared to their sole herbicides of Imazethapyr 100 g/ha (49.3\%) and Quizalofop-ethyl @ $50 \mathrm{~g} /$ ha $(48.4 \%)$. Post emergence application of imazethapyr is responsible for inhibition of acetolactate synthase (ALS) or acetohydroxyacid synthase (AHAS) in broad leaf weeds which caused destruction of these weeds at 3-4 leaf stage (Chandel and Saxena 2001). Quizalofop-ethyl inhibits the activity of the acetyl CoA carboxylase enzyme, which is necessary for fatty acid synthesis in grassy weeds. These effects of quizalofop for controlling weeds in soybean were in confirmation with the results reported by Prachand et al. (2015). They reported $48.4 \%$ weed control efficiency by the application of quizalofop.

Yield attributes and yield: Different weed control treatments were found significantly superior to increase various growth and yield attributing characters in soybean over control treatment. Taller plants and higher numbers of yield attributes characters viz., pods per plant, number of seeds per pod and seed yield (Table 3) were recorded significantly higher under two hand weeding at 20 and 40 DAS and statistically at par with combined application of Chlorimuron Ethyl @ 09gm /ha + Quizalofop-p-ethyl@50 g /ha and Imazethapyr@35g/ha+Imazamox@35 g/ha over rest of the treatments. This might be due to providing favourable environment for crop with controlling weeds, 
Table 1. Effect of weed management practices on weed density at 50 DAS in soybean during.

\begin{tabular}{|c|c|c|c|}
\hline \multirow{2}{*}{ Treatments } & \multicolumn{3}{|c|}{ Weed density $\left(\right.$ no. $\left./ \mathbf{m}^{2}\right)$} \\
\hline & Monocot weeds & Dicot weeds & Total weeds \\
\hline Weedy check & $5.22(26.87)$ & $5.54(30.42)$ & $10.77(57.28)$ \\
\hline Weed free (Twice weeding at $20 \& 40$ DAS) & $2.17(4.23)$ & $2.75(7.12)$ & $4.91(11.36)$ \\
\hline Pendimethalin@1.0kg/ah PE & $4.06(16.01)$ & $4.54(20.19)$ & $8.59(36.20)$ \\
\hline Chlorimuron Ethyl@09 gm /ha PoE & $4.31(18.11)$ & $3.91(14.89)$ & $8.22(33.00)$ \\
\hline Imazethapyr@100 g /ha PoE & $3.96(15.23)$ & $3.59(12.45)$ & $7.54(27.69)$ \\
\hline Quizalofop--ethyl@ @ 50 g /ha PoE & $3.59(12.45)$ & $4.19(17.22)$ & $7.78(29.97)$ \\
\hline Pendimethalin@1.0 kg/ha + Interculture at 20 & & & \\
\hline DAS & $3.86(14.47)$ & $3.50(11.91)$ & $7.36(26.38)$ \\
\hline $\begin{array}{l}\text { Chlorimuron Ethyl @09 gm /ha + Quizalofop-- } \\
\text { ethyl@50 g/ha } \\
\text { Imazethapyr@35 g/ha + }\end{array}$ & $2.65(6.60)$ & $2.83(7.59)$ & $5.48(14.19)$ \\
\hline Imazamox@35g/ha & $3.10(9.13)$ & $3.03(8.74)$ & $6.13(17.88)$ \\
\hline $\operatorname{LSD}(\mathrm{P}=0.05)$ & 0.59 & 0.65 & 0.78 \\
\hline
\end{tabular}

Figures in the parentheses are the original value and the data is subjected to square root transformation.

Table 2. Effect of weed management practices on weed dry matter and weed control efficiency at 50 DAS in soybean.

\begin{tabular}{|c|c|c|c|c|}
\hline \multirow{2}{*}{ Treatments } & \multicolumn{3}{|c|}{ Weed dry weight $\left(\mathrm{g} / \mathrm{m}^{2}\right)$} & \multirow{2}{*}{$\begin{array}{r}\text { Weed control } \\
\text { efficiency }(\%)\end{array}$} \\
\hline & Monocot weeds & Dicot weeds & Total weeds & \\
\hline Weedy check & 24.58 & 30.83 & 55.42 & 0.00 \\
\hline Weed free (Twice weeding at $20 \& 40$ DAS) & 8.83 & 13.52 & 22.35 & 59.67 \\
\hline Pendimethalin@1.0kg/ah PE & 19.78 & 22.30 & 42.08 & 24.06 \\
\hline Chlorimuron Ethyl@09 gm /ha PoE & 20.47 & 16.17 & 36.63 & 33.89 \\
\hline Imazethapyr@100 g /ha PoE & 19.66 & 17.45 & 37.11 & 33.03 \\
\hline Quizalofop--ethyl @ 50 g /ha PoE & 15.48 & 21.82 & 37.30 & 32.69 \\
\hline $\begin{array}{l}\text { Pendimethalin@1.0 kg/ha + Interculture at } \\
20 \text { DAS }\end{array}$ & 14.50 & 17.93 & 32.43 & 41.47 \\
\hline $\begin{array}{l}\text { Chlorimuron Ethyl @ } 09 \mathrm{gm} / \mathrm{ha}+\text { Quizalo- } \\
\text { fop--ethyl@ } 050 \mathrm{~g} / \mathrm{ha} \\
\text { Imazethapyr@35 g/ha+ }\end{array}$ & 10.70 & 15.92 & 26.62 & 51.97 \\
\hline Imazamox@35g/ha & 11.58 & 14.42 & 26.00 & 53.08 \\
\hline $\operatorname{LSD}(\mathrm{P}=0.05)$ & 3.89 & 4.53 & 5.88 & - \\
\hline
\end{tabular}

Table 3. Effect of weed management practices on plant height, yield attributes, yield and economics of soybean.

\begin{tabular}{lcccccc}
\hline Treatments & $\begin{array}{c}\text { Plant } \\
\text { height } \\
\text { (cm) }\end{array}$ & $\begin{array}{c}\text { Pods/ } \\
\text { plant } \\
\text { (No.) }\end{array}$ & $\begin{array}{c}\text { Seeds/ } \\
\text { pod (No.) }\end{array}$ & $\begin{array}{c}\text { Seed } \\
\text { yield (kg/ } \\
\text { ha) }\end{array}$ & $\begin{array}{c}\text { Net } \\
\text { returns } \\
\text { (Rs/ha) }\end{array}$ & $\begin{array}{c}\text { B:C } \\
\text { ratio }\end{array}$ \\
\hline Weedy check & 30.1 & 18.0 & 1.33 & 1091 & 22176 & 2.30 \\
Weed free (Twice weeding at 20 \& 40 DAS) & 53.8 & 32.5 & 2.32 & 1782 & 44172 & 3.21 \\
Pendimethalin @ 1.0 kg/ah PE & 41.3 & 23.9 & 1.64 & 1430 & 33060 & 2.79 \\
Chlorimuron Ethyl @ 09 gm /ha PoE & 45.5 & 25.3 & 1.71 & 1471 & 35406 & 3.02 \\
Imazethapyr @ 100 g/ha PoE & 47.5 & 26.8 & 1.73 & 1558 & 37188 & 2.97 \\
Quizalofop--ethyl @ 50 g/ha PoE & 43.3 & 24.5 & 1.63 & 1542 & 36912 & 2.98 \\
Pendimethalin @ 1.0 kg/ha + Interculture at & 52.2 & 27.8 & 1.83 & 1584 & 37614 & 2.94 \\
20 DAS & & & & & & \\
Chlorimuron Ethyl @ 09 gm /ha + Quizalo- & 53.1 & 32.0 & 2.23 & 1723 & 42978 & 3.26 \\
fop--ethyl @ 50 g/ha & & & & & & \\
Imazethapyr @ 35 g/ha + & 51.5 & 31.5 & 2.05 & 1697 & 42142 & 3.22 \\
Imazamox @ 35 g/ha & 3.49 & 3.03 & 0.28 & 73.96 & - & - \\
LSD ( P=0.05)
\end{tabular}

which reduces the competition of crop with weeds for space, air sunlight, moisture and nutrients. Further, Combined application of Chlorimuron Ethyl @ 09gm /ha + Quizalofop-p-ethyl@50 g /ha and Imazethapyr@35g/ha+Imazamox@35g/ha produced better growth and yield attributing character as compared to their sole herbicide applications and weedy check. Similar results were also obtained by Prachand et al. (2015) in their study, they reported maximum plant height $(64.1 \mathrm{~cm})$ and highest number of pods per plant (45.3) under Imazethapyr @ 35 g /ha + Imazamox@35 g/ha.

The seed yield was lowest in the plots under weedy check $(1091 \mathrm{~kg} / \mathrm{ha})$ due to severe competition stress right from crop establishment up to the end of critical period of crop growth, leading to poor growth parameters and yield attributing traits and finally the yield. All the treated plots receiving either manual weeding or 
herbicidal treatments produced higher yield over weedy check plots. Twice hand weeding treatment produced the maximum seed yield and proved its superiority over all the treatments. Similar results were also observed by Yadav et al. (2015) in their finding and reported highest seed yield of blackgram in weed free (twice hand weeding) plot over all the treatments which was followed by Imazethapyr + Imazamox and pendimethalin + imazethapyr treatments. Among the sole herbicides treatment Imazethapyr @ $100 \mathrm{~g} / \mathrm{ha}$ recorded the highest yield, however in herbicidal treatment combinations, combined application of Chlorimuron Ethyl@09 gm /ha + Quizalofop-ethyl@50 $\mathrm{g} / \mathrm{ha}$ recorded the highest yield $(1723 \mathrm{~kg} / \mathrm{ha})$ followed by Imazethapyr@35g/ha+Imazamox@35 g/ha (1697 kg/ha) and being at par to hand weeding twice (1782 kg/ha). Singh et at. ( 2015) also reported 37.25\% and 26.04\% higher yield in tank mixed herbicide of Imazethapyr@35g/ha+Imazamox@35 g/ha and Chlorimuron Ethyl@09 gm /ha + Quizalofop-ethyl (a) $50 \mathrm{~g} / \mathrm{ha}$, respectively over control. Excellent weed free conditions, provided congenial environment for better growth and development of growth parameters, yield attributes and in turn the seed yield.

Economics: Maximum net returns of Rs 44,172/ha was found with weed free (twice hand weeding) treatment which was followed by Chlorimuron Ethyl @ 09gm /ha + Quizalofop-ethyl @ 50 g /ha (Rs. 42,978) and Imazethapyr@35g/ha+Imazamox@35g/ha (Rs. 42,142). However, highest B:C ratio was recorded in Chlorimuron Ethyl + Quizalofop-ethyl (3.26) and closely followed by Imazethapyr + Imazamox (3.22) and weed free (3.21). The low investment under combined application of herbicides coupled with good economic yield might be the reason for higher net monetary return and Benefit Cost ratio over alone application of herbicide. Singh et al. (2015) also reported highest $\mathrm{B}: \mathrm{C}$ ration in combined application of Imazethapyr + Imazamox (2.58) and Chlorimuron Ethyl + Quizalofop-ethyl (2.39) against weed check (1.87). Similar finding had also been reported by Kewat et al. (2000) , Tiwari et al. (2007) and (Prachand et al., 2015 .

\section{Conclusion}

The results of this experiment revealed that among the weed management practices, application of Chlorimuron Ethyl 09gm /ha + Quizalofop-ethyl $50 \mathrm{~g} / \mathrm{ha}$ as post emergence was the best weed management practice in soybean to obtain greater yield and higher $\mathrm{B}: \mathrm{C}$ ratio (3.26). Weed free (Twice hand weeding) and Imazethapyr@35g /ha+Imazamox@35 g/ha were also found equally effective with B:C ratio of 3.21 and 3.22 , respectively and found significantly superior over sole herbicides and weedy check.

\section{REFERENCES}

Anonymous (2014). Agricultural Statistical at a Glance, Directorate of Economics and Statistics, Department of Agriculture and Cooperation, Government of India, New Delhi.

Bineet M, Anda, G. and Mohamed, T.A. (2001). Herbicide mixture in agriculture: a review, pp. 236. In: Proceeding of Biennial Conference, Indian Society of Weed Science, held at Bangalore

Chandel, A.S. and Saxena, S.C. (1998). Technology for raising soybean productivity in Uttar Pradesh. Indian Farm, 38: $10-12$

Chandel, A.S. and Saxena, S.C. (2001). Effect of some new post - emergence herbicides on weed parameters and seed yield of soybean. Indian Jr. Agronomy, 46 (2): 332-338

Kewat, M.L., Pandey, J., Yaduraju, N.T. and Kulshreshthra, G. (2000). Economic and eco-friendly weed management in soybean. Indian J. Weed Sci., 32 (3\&4): 135-139

Malik, R.S., Ashok, Yadav. and Malik, R.K. (2006). Integrated weed management in soybean. Indian Indian $J$. Weed Sci., 38(1\&2): 65-68

Prachand, S., Kalhapura, A. and Kubde, K.J. (2015). Weed management in soybean with pre and post emergence herbicides. Indian J. Weed Sci., 47(2): 163-165

Singh, Guriqbal. (2007). Integrated weed management in soybean (Glycine max). Indian J. Agri. Sci., 77 (10): 675-676

Singh, Mahender., Tomar, I.S., Singh, V.K. and Garg, S.K. (2015). Effect of integrated weed management on yield of soybean (Glycine max. L.). Bhartiya Krishi Anusandhan Patrika, 30(4): 204-205

Yadav, K.S., Dixit, J.P. and Prajapati, B.L. (2015). Weed management effects on yield and economics of black gram. Indian J. Weed Sci., 47(2): 136-138 